\title{
Quality characteristics of Nuruk with different water contents during fermentation period
}

\author{
Ji-Young Mun, Joo-Yeon Kim, So Young Kim, Han-Seok Choi, Soo-Hwan Yeo* \\ Fermented processing Food Science Division, National Institute of Agricultural Science, RDA, Wanju 55365, Korea
}

\section{가수량에 따른 누룩의 발효기간별 품질 특성}

\author{
문지영 · 김주연 · 김소영 · 최한석 · 여수환* \\ 농촌진흥청 국립농업과학원 발효가공식품과
}

\begin{abstract}
To investigate the effects of water contents on the characteristics of Nuruk, three sets of Nuruks were prepared with water contents of $20 \%, 26 \%$, and $30 \%$. Morphological shapes, intemal temperature, physicochemical properties, enzyme activity, metabolites, and volatile chemical patterns were monitored for 30 days. Regardless of the water content, the morphological shapes showed that the mold mycelia were extended to the inside and the weight and size were decreased in the three Nuruks. The internal temperature was the highest $\left(39.7^{\circ} \mathrm{C}\right)$ for a water content of $26 \%$. Higher water contents were accompanied by lower $\mathrm{pH}$. a-Amylase activity was increased 1.5-fold in Nuruk containing $30 \%$ water. Acidic protease activity was also the highest $(1,800 \mathrm{U} / \mathrm{g})$ after 20 days for Nuruk with $30 \%$ water content. In addition, the levels of saccharides (glucose, galactose, and fructose) were increased 2.4-, 1.97-, 1.5-fold, respectively, with higher water contents. Organic acid (lactic acid) content was the highest (2.2 $\mathrm{mM}$ ) in Nuruk containing 30\% water. Free amino acid (glutamate and proline) contents in Nuruk with $26 \%$ and $30 \%$ water contents were higher than those in the $20 \%$. The volatile patterns were different in the three Nuruks with $20 \%, 26 \%$ and $30 \%$ water contents. This study suggests that the range of water content of $26-30 \%$ might be appropriate for the production of Nuruk with high saccharification and proteolytic activities.
\end{abstract}

Key words : Nuruk, ${ }^{1} \mathrm{H}-\mathrm{NMR}$, electronic nose, water contents

\section{서 론}

재래누룩은 소맥, 보리, 옥수수, 쌀, 귀리, 호밀 등과 같은 전분질을 빻은 다음, 물을 뿌린 후 성형하여 수일간 자연계 의 미생물이 착생하여 증식하는 방식으로 제조되며(1), 우 리나라 전통주인 막걸리 등의 양조에 있어 쌀 등의 전분질 원료를 분해하는 아밀라아제(amylase)를 비롯한 발효 미생 물의 스타터(starter)로서 중요한 역할을 하고 있다. 발효제 는 사용하는 원료와 지역에 따라 술의 맛, 향기, 색 등의

*Corresponding author. E-mail : yeobio@korea.kr Phone : 82-63-238-3609, Fax : 82-63-238-3843

Received 13 July 2018; Revised 6 August 2018; Accepted 19 August 2018.

Copyright (c) The Korean Society of Food Preservation. All rights reserved.
품질을 변화시키므로 우리 술의 품질 향상에 가장 중요한 인자라 할 수 있다(2). 발효제는 제조 방법에 따라 자연 환경 중에 존재하는 미생물이 증식되어 만들어지는 재래누 룩과 살균한 전분질 원료에 Aspergillus luchuensis 또는 $A$ oryzae 등의 순수 배양된 발효종균을 접종하여 만드는 개량 누룩으로 분류한다(3). 재래누룩은 누룩에 존재하는 다양 한 미생물들의 발효력, 효소 및 유기산 생성 등의 차이로 인해 주류의 맛과 향이 다양한 장점이 있으나, 발효과정에 잡균으로 인한 오염의 문제가 있어 발효주의 산패가 진행될 수 있다는 단점이 존재한다. 반면, 개량누룩은 담금 과정에 서 전분질을 분해하는 효소원으로만 이용되며, 알코올 발 효를 진행하기 위해 효모를 배양한 주모를 첨가해야만 술덧 의 안전한 발효, 잡균오염 방지 및 발효 시간이 단축되면서 항상 일정한 품질의 발효주를 얻을 수 있다 $(4,5)$. 이러한 장점을 가진 개량누룩은 상업적으로 쉽게 응용할 수 있는 
일본의 종균(Aspergillus 속)과 종국제조 기술들이 우리나라 전통 문화와 발효식품에 영향을 주고 있어 우리 술의 명맥 을 이어가는데 걸림돌이 되고 있다(6). 따라서, 고문헌에 수록된 재래누룩의 품질을 향상시키기 위한 일환으로 원 료, 가수량 및 발효공정(온도, 시간 등) 개선 및 문헌 속의 다양한 누룩 연구를 통해 상업적 활용으로서의 접근이 필요 한 시점이다. 현재까지 누룩에 관한 연구로는 누룩에 생육 하는 곰팡이, 효모 및 젖산균 등의 분리 및 동정에 관한 연 구뿐만 아니라(2,6-10), 각종 종균들을 조합한 개량누룩 과 재래누룩을 이용한 발효주의 품질 및 이화학적 특성에 관한 연구(11-14), 백국균인 A luchuensis로 제조한 누룩으 로 빚은 막걸리의 휘발성 향기성분 분석(15) 및 누룩의 생리 활성에 관한 연구(16-19)등이 보고되었다. 그러나 대부분의 연구가 누룩을 이용하여 제조된 발효주의 품질 특성에 관한 내용에만 치우쳐 있어 누룩 자체의 발효 특성에 관한 연구 는 부족한 실정이다. 특히, 우리 술 제조에 있어 효모와 유산균은 산패와 감패를 억제하는 역할을 하지만 본 연구에 서는 다양한 미생물 중 당화력을 가지는 곰팡이를 대상으로 고문헌(20)에 기술된 보리와 녹두즙을 이용하여 낮은 온도 에서 발효시킨 향온곡 제법을 원료(밀, 보리, 녹두)와 가수 량 등을 변형시켜 발효기간에 따른 누룩의 품질 특성을 분석하고 이의 결과를 상업적 대량생산을 위한 기초 자료로 제공하고자 한다.

\section{재료 및 방법}

\section{실험재료}

본 연구에 사용된 밀은 광주지역에서 재배(2014년)한 우 리밀(금강밀)을, 보리 및 녹두는 전남 해남지역에서 재배 (2014년)한 것을 광천유통(Suwon, Korea)을 통해 구입하여 사용하였다.

\section{누룩제조}

고사촬요(20)에 기술된 향온곡 제조는 보리를 주원료로 하여 녹두 즙을 첨가한 후, 낮은 온도에서 발효시키는 방법 이나, 본 연구에서는 이를 변형시켜 원료(밀, 보리, 녹두)와 가수량을 달리하여 다음과 같이 제조하였다. 우리밀, 보리 및 녹두를 롤러밀로 분쇄한 후, 7-mesh $(2.8 \mathrm{~mm})$ 체로 3회 내린 후, 누룩 총량에 대한 가수량 $(20,26,30 \%(\mathrm{v} / \mathrm{w}))$ 을 달리 하여 살수 혼합한 후, 1 시간 동안 실온에서 침윤시켜 원료별 비율(보리:녹두:밀 $=46.5 \%: 7 \%: 46.5 \%$ )로 혼합한 다음, 성형 틀을 이용하여 $340 \mathrm{~g}$ 씩 누룩을 성형하였다. 제조된 누룩은 $36^{\circ} \mathrm{C}, 70 \%$ 습도조건에서 30 일간 발효(VS- $1203 \mathrm{PFHLN}$, Vision Scientific Co., Ltd., Daejeon, Korea)시켰으며 이들 누룩의 품질을 분석하기 위해, 발효기간별 $(0,3,6,10,20$, 및 30 일)로 샘플링을 한 후, $35^{\circ}$ 에서 24시간 건조(DS-80-3,
Dasol Scientific Co., Ltd., Hwaseong, Korea)하여 사용하였 다.

\section{누룩의 외형적 특성분석}

제조된 누룩의 무게는 micro weighing scale(MW- П 6000 N, CAS Co., Seoul, Korea)로 측정하고, 크기는 digimatic caliper(CD-20CPX, Mitutoyo Co., Kawasaki, Japan)로, 수분함량은 moisture analyzer(MX-50, AND Co., Tokyo, Japan)로 측정하였다.

\section{발효기간별 누룩의 품온 측정}

누룩 발효 중 미생물 생육에 의해 생성되는 품온 변화를 측정하기 위해 $\mathrm{HOBO}^{\circledR}$ 사의 data logger U12-013(U22-001, Onset computer Corporation, Bourne, MA, USA)을 이용하여 6시간 간격으로 측정하였다(21).

\section{이화학적 특성 분석}

pH는 pH meter(Orion 3 star, Thermo scientific Co., MA, $\mathrm{USA}$ )로, 총산도는 일정량의 시료를 취하여 여과지로 여과 한 검체 $10 \mathrm{~mL}$ 를 $100 \mathrm{~mL}$ 삼각플라스크에 취한 다음, $0.5 \%$ phenolphthalein 지시약을 2-3방울 떨어뜨리고 $0.1 \mathrm{~N} \mathrm{NaOH}$ 로 적정될 때까지 중화 적정하였으며 소비된 용액의 양을 lactic $\operatorname{acid}(\%)$ 로 표시하였다. 아미노산도는 여과지로 여과 한 검체 $10 \mathrm{~mL}$ 에 $0.5 \%$ phenolphthalein 지시약을 2-3방울 떨어뜨린 후, $0.1 \mathrm{~N} \mathrm{NaOH}$ 로 적정하고 여기에 중성 포르말 린 용액 $5 \mathrm{~mL}$ 을 가하여 유리된 산을 $0.1 \mathrm{~N} \mathrm{NaOH}$ 로 적정하 여 담홍색이 될 때까지 소비된 $0.1 \mathrm{~N} \mathrm{NaOH}$ 의 $\mathrm{mL}$ 수로 표시 하였다(22).

\section{효소활성 측정}

a-Amylase 활성은 $1 \%$ 전분용액 $2 \mathrm{~mL}$ 을 시험관에 취해, $40^{\circ} \mathrm{C}$ 에서 5 분간 예열한 후, 효소액 $0.1 \mathrm{~mL}$ 을 가해서 반응을 개시하고, 반응액을 $0.1 \mathrm{~mL}$ 씩 1 분 간격으로 미리 요오드 용액 $10 \mathrm{~mL}$ 을 넣어둔 시험관에 넣어 혼합하여 생성된 색을 $25^{\circ} \mathrm{C}$ 에서 유지하다가 두꺼운 $10 \mathrm{~mm}$ 을 통과하여 $670 \mathrm{~nm}$ 색 을 비교하고, 투과율 $\mathrm{T} \%$ 을 측정하였다. 효소활성(unit)은 Wohlgemuth value에 준한 아래 식으로 산출하였다(22).

$$
\mathrm{U}(\text { units } / \mathrm{g})=\frac{12.75 \times\left(\mathrm{T}_{30 \mathrm{~min}}-\mathrm{T}_{0 \mathrm{~min}}\right)}{30 \mathrm{~min}} \times \text { 희석배수 }
$$

$\mathrm{T}_{30 \mathrm{~min}}$ : 30 분간 효소반응을 시킨 후의 투과도

$\mathrm{T}_{0 \mathrm{~min}}$ : 효소반응을 시키기 전의 투과도

Glucoamylase 활성은 $2 \%$ 전분용액 $1 \mathrm{~mL}$ 에 $0.2 \mathrm{M}$ 초산 완충액 $0.2 \mathrm{~mL}$ 를 가하고 $40^{\circ} \mathrm{C}$ 에서 5 분간 예열한 후, 효소액 $0.1 \mathrm{~mL}$ 를 가해서 $40^{\circ} \mathrm{C}$ 에서 20 분간 반응시키고, $1 \mathrm{~N} \mathrm{NaOH}$ 
용액 $0.1 \mathrm{~mL}$ 을 첨가하여 반응을 정지시켜 30 분간 방치하고 $1 \mathrm{~N}$ 염산용액 $0.1 \mathrm{~mL}$ 를 가해 중화하였다. 본 실험에 사용한 대조구는 전분용액 $1 \mathrm{~mL}$ 에 $0.2 \mathrm{M}$ 초산 완충액 $0.2 \mathrm{~mL}$ 을 가해 $40^{\circ} \mathrm{C}$ 에서 5 분간 예열하였다. 대조구는 시료와 동일하 게 $1 \mathrm{~N}$ 염산용액 $0.1 \mathrm{~mL}$ 를 가해 중화시켰고, 효소 활성은 DNS법으로 환원당을 측정하여 생성된 포도당량으로 하였 다. Glucoamylase 활성은 가용성 전분으로부터 $40^{\circ} \mathrm{C}$ 에서 60 분간 $1 \mathrm{mg}$ 의 포도당을 생성하는 활성을 1 unit로 하였으 며, 시료 $1 \mathrm{~g}$ 의 glucoamylase 활성은 다음의 식으로 산출하 였다(22).

$$
\begin{aligned}
\mathrm{U}(\text { units } / \mathrm{g})= & \text { 생성 포도당량 }(\mathrm{mg}) \times 60 / 20(\text { 반응시간 }) \\
& \times 1 / 0.1(\text { 효소량 }) \times \text { 희석배수 }
\end{aligned}
$$

Acidic protease 활성은 카제인 용액 $1.5 \mathrm{~mL}$ 에 pH 3.0 맥바인 완충액 $1.0 \mathrm{~mL}$ 와 조효소액 $0.5 \mathrm{~mL}$ 를 넣고 $40^{\circ} \mathrm{C}$ 에서 60 분간 반응시킨 후, $\mathrm{TCA}$ 용액 $3 \mathrm{~mL}$ 을 가해 반응을 정지시 키고 침전을 제거하였다. 이 액 $1 \mathrm{~mL}$ 에 탄산나트륨용액 $5 \mathrm{~mL}$ 와 페놀시약 $1 \mathrm{~mL}$ 을 가해서 $40^{\circ} \mathrm{C}$ 에서 30 분간 발색시 킨 후, $660 \mathrm{~nm}$ 에서 흡광도를 측정하였고, 별도로 대조구로 는 TCA용액을 가하기 직전에 효소액을 첨가하여 위의 방 법과 동일하게 하여 흡광도를 측정하고 아래 식에 의해서 효소활성을 산출하였다(22).

\section{$\mathrm{U}($ units/g)=tyrosine $(\mu \mathrm{g}) \times 6 / 1$ (반응액량 $) \times$ $1 / 0.5$ (효소액량) $\times$ 희석배수}

\section{당류, 유기산 및 유리아미노산 성분분석}

당류, 유기산 및 유리아미노산 분석은 ${ }^{1} \mathrm{H}-\mathrm{NMR}$ (Proton Nuclear Magnetic Resonance)을 사용하여 분석하였다. ${ }^{1} \mathrm{H}-\mathrm{NMR}$ 측정을 위해, 제조된 3 종류의 누룩 시료로부터 $20 \mathrm{~g}$ 을 채취한 후, 증류수 $100 \mathrm{~mL}$ 을 가하고 실온에서 3시간 침출한 누룩 추출물을 $\mathrm{NaOH}$ 나 $\mathrm{HCl}$ 을 사용하여 $\mathrm{pH}$ 를 6.0 으 로 조정하고, $1 \mathrm{~mL}$ 씩 동결건조 하였다. NMR peak annotation 및 농도분석에 요구되는 내부 표준물질인 3-(trimethylsityl)-1-propane-sulfonic acid(DSS)를 $5 \mathrm{mM}$ 농 도로 용매인 detrium oxide(D2O)에 용해하고, 이 용액 1 $\mathrm{mL}$ 를 동결건조 누룩에 첨가하여 용해 원심분리(13,200 $\mathrm{rpm}, 10 \mathrm{~min})$ 하여 비 용해체를 분리시켜 상등액을 취하였 다. 상등액을 $600-\mathrm{mHz}$ NMR 전용 튜브에 넣어 NMR 분석 기기(NMR 600-Mhz, Varian Inc., Palo Alto, CA, USA)를 통해 분석하고, Chenomx NMR suit ver 8.12(Chenomx Inc, Edmonton, Alberta, Canada)를 사용하여 각각의 성분을 분 석하였다.

\section{다중 향기성분 분석}

가수량을 달리하여 제조한 각각의 시료 $0.5 \mathrm{~mL}$ 을 $10 \mathrm{~mL}$
튜브에 넣고, $40^{\circ} \mathrm{C}$ 에서 30 분간 $500 \mathrm{rpm}$ 으로 교반하고 전자 코(Fast GC based HERACLES flash electronic nose, Alpha Mos, Toulouse, France)를 이용하여 측정하였다. 분석방법 으로는 2개의 column(Agilent capillary GC column, DB-5 polar, DB-1701 slightly polar)을 사용하고, FID로 검출하였 다. Injection은 syringe type $(5.0 \mathrm{~mL}$, headspace)으로 column 온도가 $25^{\circ} \mathrm{C}$ 로 유지된 상태에서 column head pressure 1.0 $\mathrm{psi}$ 로 주입하였다. 분석 시 injector 온도는 $200^{\circ} \mathrm{C}$, detector $200^{\circ} \mathrm{C}$, injector pressure $1.0 \mathrm{psi}$, detector pressure $39.0 \mathrm{psi}$ 로 하였다. 시료분석 전 kovats(Custom alkanes blend standard) 를 이용하여 C6-C16까지의 peak값을 얻어 standard로 이용 하였다. 또한 분석 결과는 R project(ver 3.2.1) 프로그램을 이용하여 결과 값을 그래프로 나타내었다.

\section{통계처리}

통계처리는 SAS(Statistical Analysis System)에 의한 분산 분석(ANOVA)에 의해 검증하였으며, Ducan's multiple range test로 유의성을 검증하였다(23).

\section{결과 및 고찰}

\section{누룩의 외형적 특성}

가수량을 달리하여 제조한 누룩의 외형적 특성 변화를 발효기간 동안 정성 및 정량적으로 분석하였다. Fig. 1은 제조한 누룩에 곰팡이가 외부에서 내부로 침투하는 것을 발효기간에 따라 나타내었으며, Table 1은 제조한 누룩의 무게, 크기, 및 수분함량의 변화를 정량적으로 나타낸 것이 다. 제조한 3종류의 누룩은 가수량의 차이와는 상관없이 발효기간이 경과함에 따라 곰팡이의 균사(황국균 및 백국 균 등)가 내부까지 침투하여 생육하는 것을 확인할 수 있었 고(Fig. 1), 누룩의 중량과 크기는 가수량에 따른 차이는 없었지만 발효기간 동안 전체적으로 중량과 크기가 소폭 감소하였는데, 이는 발효기간에 따른 수분함량 변화에 기 인된 것으로 보인다.

발효기간 동안 누룩의 수분함량은 모든 누룩 시험구에서 0.43-0.5배 정도 감소하였다. 특히, 가수량 $30 \%$ 누룩에서 수분함량의 감소폭이 $-12.23 \%$ 로 가장 크게 나타났지만 발 효 종료시점에는 모든 누룩의 수분함량이 가수량에 따른 차이와 상관없이 9.1-9.9\%로 비슷한 수치를 나타내었다. 따라서 누룩제조에서 가수량은 발효기간 동안 일정량 감소 를 통해 발효가 끝난 이후, 모든 누룩의 수분함량이 유사한 값을 나타내었다. 이는 발효기간별 누룩 시료를 채취하여 $35^{\circ} \mathrm{C}$ 에서 24 시간 건조 후, 분석한 결과로서 제조한 누룩의 외형적 특성은 유사하게 유지되었다.

\footnotetext{
누룩의 품온 변화

가수량을 달리하여 제조한 누룩의 품온 변화를 발효기간
} 


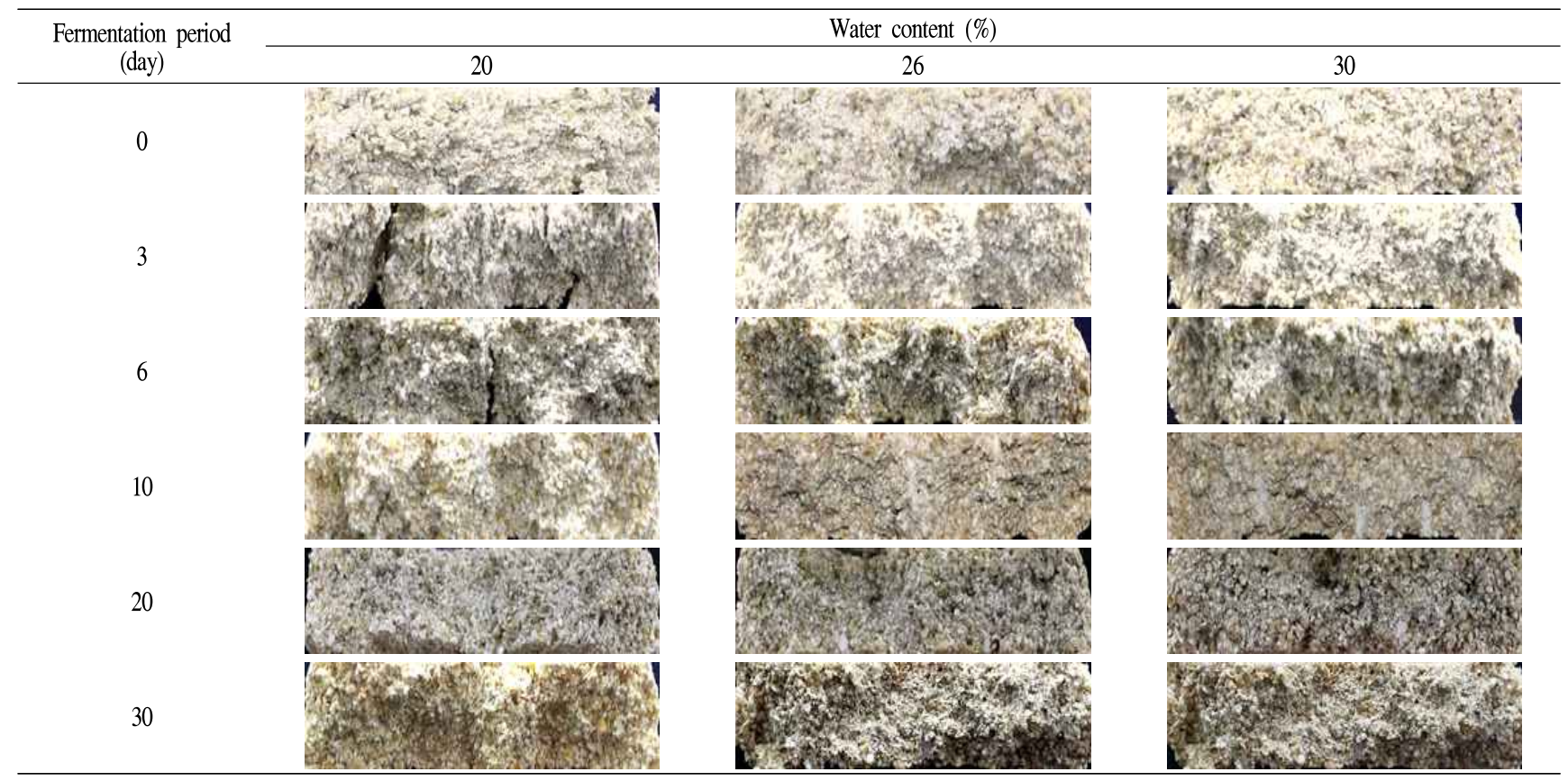

Fig. 1. Morphological shapes of Nuruk with different water contents during fermentation period.

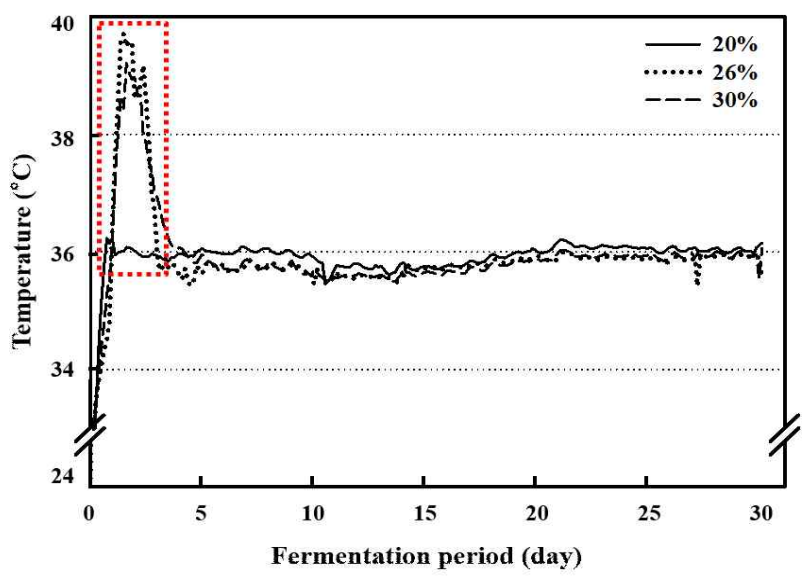

Fig. 2. The internal temperature changes of Nuruk with different water contents during fermentation period.

별로 분석한 결과를 Fig. 2에 나타내었다. 발효 0 일째부터 누룩의 품온이 증가하여 발효 2 일째 최고 온도를 나타내었 고, 이후 온도가 떨어지기 시작하여 발효 4 일째부터는 $36^{\circ} \mathrm{C}$ 로 발효 30일까지 일정하게 유지되었다. 또한, 가수량별 누룩의 품온 변화는 가수량 $26 \%$ 누룩에서 가장 높은 품온 $\left(39.7^{\circ} \mathrm{C}\right)$ 을 나타내었고, 첨가한 가수량이 많을수록 품온의 최고값은 1-2일 정도 늦게 나타나는 것을 알 수 있었다. 발효기간에 따른 누룩의 품온 차이는 누룩에 생육하는 다양 한 미생물들이 증식하면서 내는 호흡열에 따른 차이로 생긴 다. 이전에 Choi 등(24)이 보고한 석탄주 제조 시 사용한 시판누룩(밀누룩)은 업체별 사용한 누룩 원료와 가수량 차 이는 있었지만 누룩의 품온 결과가 아니라 석탄주 발효
중의 술덧의 변화와 일부 유사한 결과가 도출되었다. 본 연구에서의 누룩제조 시 품온 변화는 누룩 미생물과 사용 원료 및 가수량 등에 영향을 받는 것으로 사료된다.

\section{누룩의 이화학적 특성}

가수량 및 발효기간에 따른 누룩의 이화학적 특성 변화 를 Fig. 3 에 나타내었다. 누룩의 $\mathrm{pH}$ 는 발효기간 동안 감소하 였고, 가수량이 많은 누룩일수록 $\mathrm{pH}$ 는 더 낮게 나타났다. 이는 발효 초기, 탈 아미노산에 의한 유기산 형성과 효모 증식으로 인한 인산 소비와 암모니움 이온 흡수로 기인된 결과로 여겨진다(25). 또한, 누룩의 산도는 발효 5 일까지 증가하다가 이후부터 감소하여 발효 30일째에는 47-54.7\% 감소하였다. 누룩의 아미노산도는 발효기간이 경과함에 따 라 증가하다가 발효 30일째에는 54-57.4\%로 감소하였다. 아미노산도는 누룩 중에 함유된 단백질이 발효과정 중 미생 물이 생산하는 acidic protease와 peptidase 등의 단백질 분해 효소작용으로 생성되어 발효주의 감칠맛 등에 영향을 주는 것으로 보고된 바 있다(26).

\section{누룩의 효소활성 변화}

가수량을 달리하여 제조한 누룩의 효소활성 변화를 Fig. 4에 나타내었다. 가수량에 따른 누룩의 a-amylase 활성은 발효 6일까지 증가한 후, 10 일부터 $2.8-11 \%$ 감소하였고, 가수량 $30 \%$ 누룩이 $20 \%$ 누룩보다 a-amylase 활성이 약 1.5 배 높았다. 발효기간에 따른 누룩의 glucoamylase 활성 은 발효 초기부터 꾸준히 증가하다 발효 10 일 이후부터 감소하였으며, 가수량 $20 \%$ 누룩이 발효 20 일째 $4,424.6$ 
units $/ \mathrm{g}$ 으로, $26 \%$ 및 $30 \%$ 누룩과 비교하여 유의적으로 glucoamylase 활성이 1.1 배 높았다. $\mathrm{Kim}$ 등(27)의 연구에

Table 1. Morphological characteristics of Nuruk with different water contents during fermentation period

\begin{tabular}{|c|c|c|c|c|}
\hline $\begin{array}{c}\text { Nuruk } \\
\text { water content(\%) }\end{array}$ & $\begin{array}{c}\text { Fermenta } \\
\text { tion } \\
\text { period } \\
\text { (day) }\end{array}$ & Weight (g) & $\begin{array}{c}\text { Size } \\
(\mathrm{mm})(\mathrm{D} / \mathrm{H})\end{array}$ & $\begin{array}{c}\text { Moisture content } \\
(\%)\end{array}$ \\
\hline \multirow{6}{*}{20} & 0 & $308.4 \pm 1.55^{1 / 22)}$ & $\begin{array}{l}123.25 \pm 0.95^{\mathrm{a}} \\
33.63 \pm 0.89^{\mathrm{ab}}\end{array}$ & $17.97 \pm 1.14^{\mathrm{a}}$ \\
\hline & 3 & $293.4 \pm 0.9^{b}$ & $\begin{array}{l}118.90 \pm 0.96^{\mathrm{b}} \\
34.69 \pm 1.37^{\mathrm{ab}}\end{array}$ & $12.00 \pm 0.3^{\mathrm{b}}$ \\
\hline & 6 & $288.9 \pm 1.93^{\mathrm{cd}}$ & $\begin{array}{l}118.47 \pm 1.24^{\mathrm{b}} \\
34.25 \pm 0.27^{\mathrm{a}}\end{array}$ & $9.47 \pm 0.46^{c}$ \\
\hline & 10 & $285.1 \pm 0.88^{d}$ & $\begin{array}{l}118.33 \pm 0.94^{\mathrm{b}} \\
34.84 \pm 0.61^{\mathrm{a}}\end{array}$ & $8.25 \pm 0.44^{\mathrm{d}}$ \\
\hline & 20 & $290.6 \pm 1.77^{\mathrm{c}}$ & $\begin{array}{l}116.7 \pm 0.66^{b} \\
32.95 \pm 0.71^{b}\end{array}$ & $8.49 \pm 0.14^{\mathrm{cd}}$ \\
\hline & 30 & $281.7 \pm 1.4^{\mathrm{e}}$ & $\begin{array}{l}118.52 \pm 2.00^{\mathrm{b}} \\
33.37 \pm 0.51^{\mathrm{ab}}\end{array}$ & $9.11 \pm 0.06^{\mathrm{c}}$ \\
\hline \multirow{6}{*}{26} & 0 & $301.5 \pm 1.45^{\mathrm{a}}$ & $\begin{array}{l}122.56 \pm 1.16^{\mathrm{a}} \\
34.83 \pm 0.78^{\mathrm{a}}\end{array}$ & $19.34 \pm 0.44^{\mathrm{a}}$ \\
\hline & 3 & $278.2 \pm 0.95^{b}$ & $\begin{array}{c}108.87 \pm 0.81^{\mathrm{c}} \\
32.71 \pm 0.7^{\mathrm{bc}}\end{array}$ & $12.93 \pm 1.28^{\mathrm{b}}$ \\
\hline & 6 & $270.3 \pm 0.51^{\mathrm{c}}$ & $\begin{array}{c}116.35 \pm 0.7^{\mathrm{b}} \\
33.25 \pm 1.00^{\mathrm{ab}}\end{array}$ & $8.83 \pm 0.44^{c}$ \\
\hline & 10 & $267.1 \pm 1.51^{\mathrm{d}}$ & $\begin{array}{l}116.22 \pm 1.52^{\mathrm{b}} \\
31.05 \pm 0.76^{\mathrm{bc}}\end{array}$ & $8.22 \pm 0.27^{c}$ \\
\hline & 20 & $257.8 \pm 1.02^{\mathrm{e}}$ & $\begin{array}{l}115.67 \pm 0.63^{\mathrm{b}} \\
31.37 \pm 0.82^{\mathrm{bc}}\end{array}$ & $8.96 \pm 0.74^{c}$ \\
\hline & 30 & $249.7 \pm 1.3^{\mathrm{f}}$ & $\begin{array}{l}115.64 \pm 0.46^{\mathrm{b}} \\
31.82 \pm 0.95^{\mathrm{c}}\end{array}$ & $9.94 \pm 0.62^{\mathrm{c}}$ \\
\hline \multirow{6}{*}{30} & 0 & $300.0 \pm 0.85^{\mathrm{a}}$ & $\begin{array}{l}121.82 \pm 0.81^{\mathrm{a}} \\
35.42 \pm 0.69^{\mathrm{a}}\end{array}$ & $21.48 \pm 1.26^{\mathrm{a}}$ \\
\hline & 3 & $268.0 \pm 1.58^{b}$ & $\begin{array}{l}105.77 \pm 1.27^{\mathrm{e}} \\
32.47 \pm 0.67^{\mathrm{b}}\end{array}$ & $13.52 \pm 0.47^{b}$ \\
\hline & 6 & $259.6 \pm 1.15^{\mathrm{c}}$ & $\begin{array}{l}116.45 \pm 1.46^{b} \\
32.96 \pm 0.75^{b}\end{array}$ & $10.35 \pm 0.46^{\mathrm{c}}$ \\
\hline & 10 & $253.7 \pm 0.81^{\mathrm{d}}$ & $\begin{array}{l}111.02 \pm 1.31^{\mathrm{d}} \\
31.86 \pm 0.86^{\mathrm{b}}\end{array}$ & $8.34 \pm 0.42^{\text {de }}$ \\
\hline & 20 & $257.7 \pm 0.7^{\mathrm{c}}$ & $\begin{array}{l}114.28 \pm 0.83^{\mathrm{c}} \\
32.27 \pm 0.45^{\mathrm{b}}\end{array}$ & $8.84 \pm 1.42^{\mathrm{e}}$ \\
\hline & 30 & $251.5 \pm 0.4^{\mathrm{e}}$ & $\begin{array}{l}115.52 \pm 0.8^{b} \\
32.13 \pm 0.16^{b}\end{array}$ & $9.25 \pm 0.56^{\mathrm{cd}}$ \\
\hline
\end{tabular}

${ }^{1)}$ Each values represents mean \pm SD $(n=3)$.

${ }^{2)}$ Values with different letters (a-f) within a column differ significantly $(\mathrm{p}<0.05)$.
의하면 누룩에 사용된 밀의 양과 가수량이 반비례일수록 a-amylase 및 glucoamylase 활성이 높은 경향을 나타내었다 고 보고한 바 있다. 본 연구의 glucoamylase 활성 결과가 이와 유사하게 나타났다. Acidic protease 활성은 발효기간 동안 대체로 증가하다 가수량 $30 \%$ 누룩은 발효 후반부에 이르러 활성이 감소하였으며, $20 \%$ 및 $26 \%$ 누룩의 활성은 일정하게 유지되었다. 특히, 가수량 $30 \%$ 누룩의 acidic protease 활성은 발효 20 일에 1,800 units $/ \mathrm{g}$ 로 가수량 $20 \%$, $26 \%$ 누룩보다 높았다.
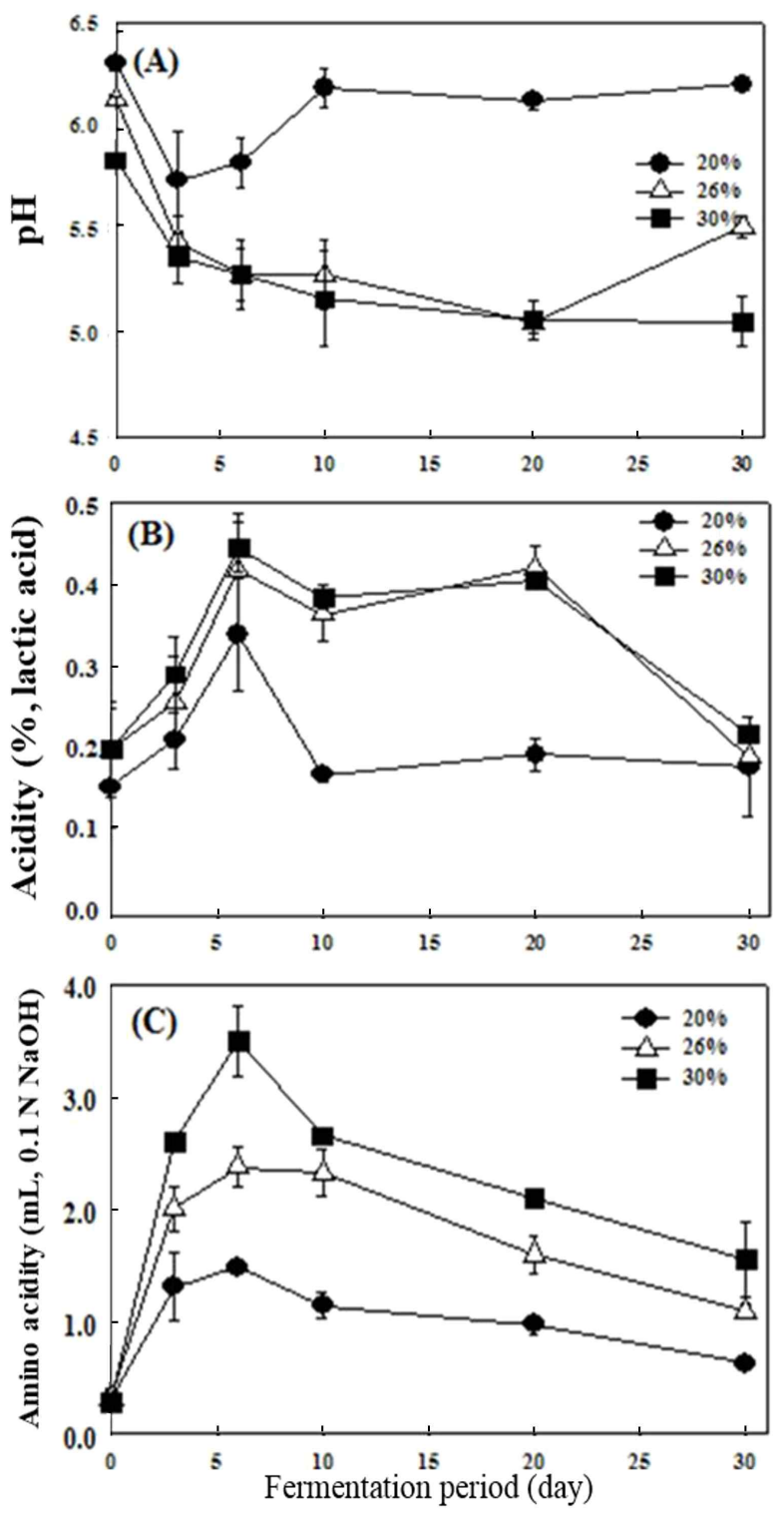

Fig. 3. Physicochemical properties of Nuruk with different water contents during fermentation period.

A, pH; B, acidity; C, amino acidity.

, $20 \%$ water contents Nuruk, $\triangle, 26 \%$ water contents Nuruk, $\square, 30 \%$ water contents Nuruk

*Values with different letters within a row differ significantly $(\mathrm{p}<0.05)$. "Values with different letters within a column differ significantly $(p<0.05)$. Each values represents mean $\pm \mathrm{SD}(\mathrm{n}=3)$. 
A

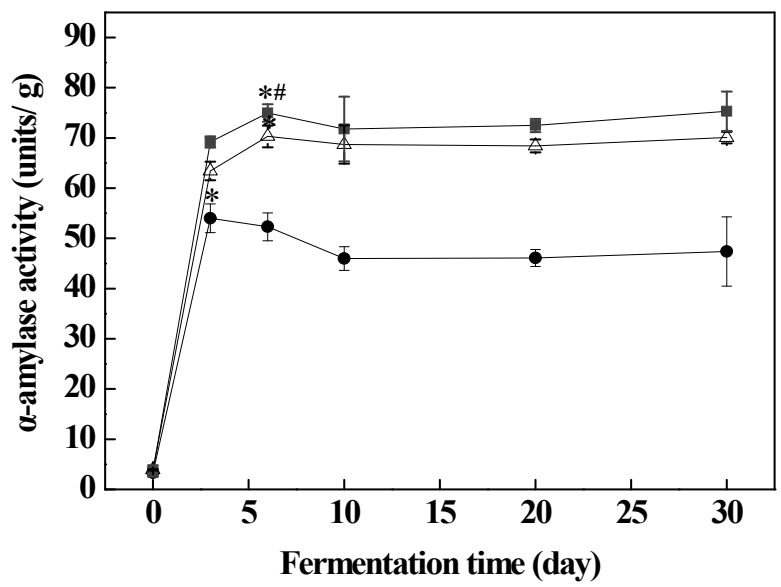

B

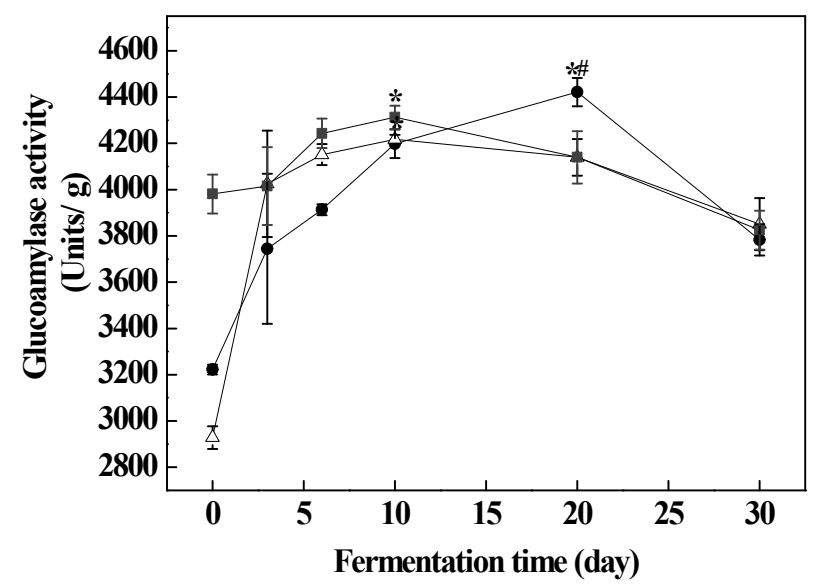

C

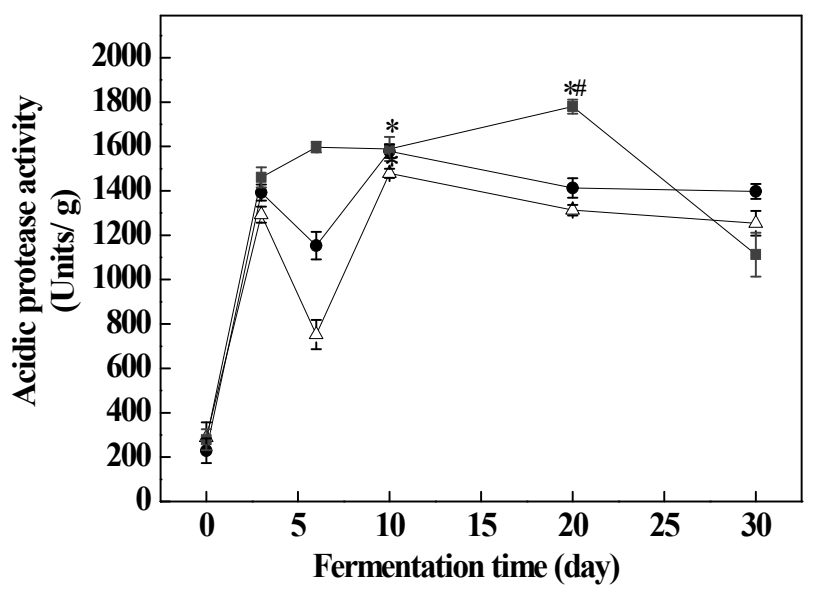

Fig. 4. Enzyme activity of Nuruk with different water contents during fermentation period.

A, a-amylase activity; B, glucoamylase activity; C, acidic protease activity $20 \%$ water contents Nuruk, $\triangle, 26 \%$ water contents Nuruk, $\mathbf{\square}, 30 \%$ water contents Nuruk

"Values with different letters within a row differ significantly $(\mathrm{p}<0.05)$. "Values with different letters within a column differ significantly $(p<0.05)$. Each values represents mean \pm SD $(n=3)$.

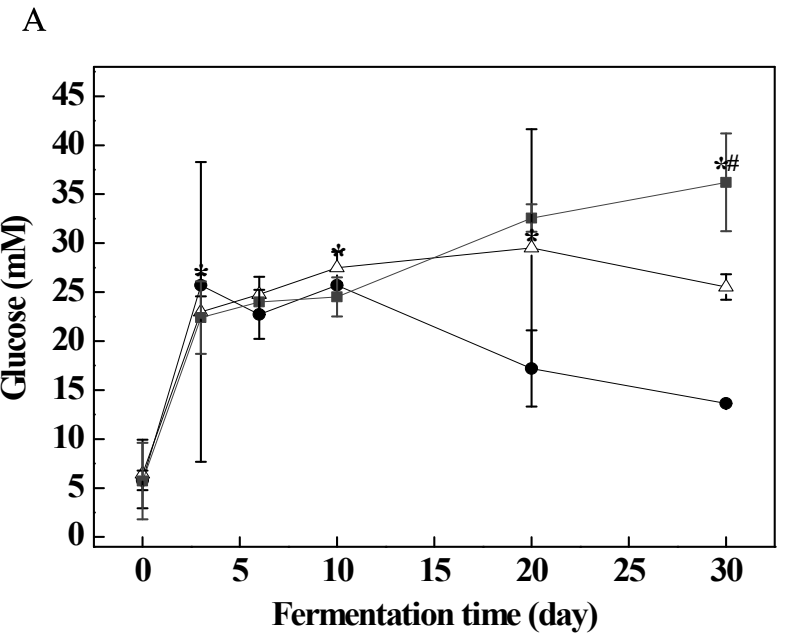

B

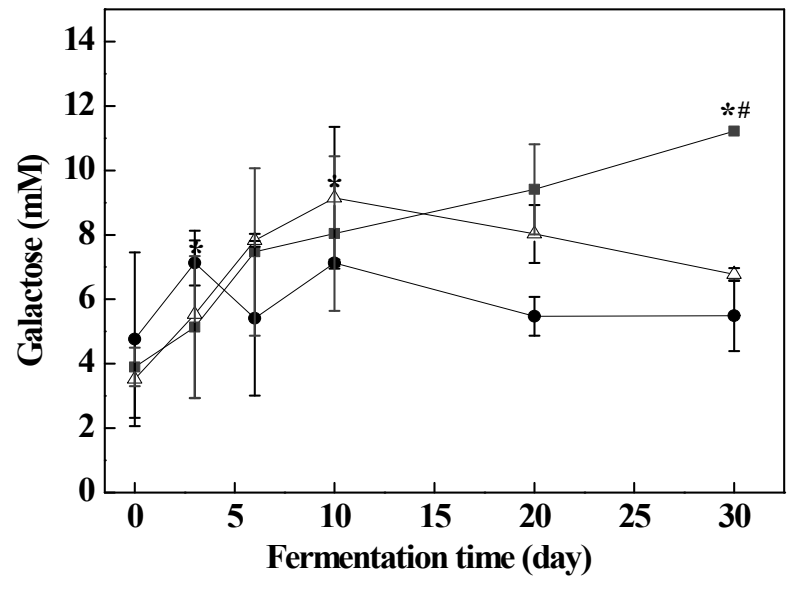

C

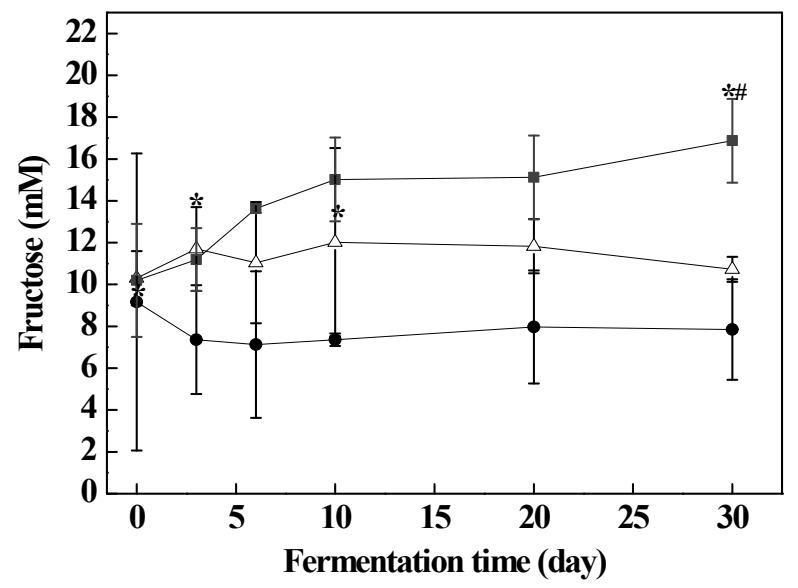

Fig. 5. Free sugar contents of Nuruk with different water contents during fermentation period.

A, Glucose; B, Galactose; C, Fructose.

, 20\% water contents Nuruk, $\triangle, 26 \%$ water contents Nuruk, $\square, 30 \%$ water contents Nuruk

"Values with different letters within a row differ significantly $(\mathrm{p}<0.05)$. "Values with different letters within a column differ significantly $(p<0.05)$. Each values represents mean $\pm S D(n=3)$. 


\section{누룩의 유리당 및 유기산 변화}

가수량을 달리하여 제조한 누룩의 유리당 함량 변화를 Fig. 5에 나타내었다. 발효기간에 따른 누룩의 주요 유리당 을 분석한 결과, glucose, fructose 및 galactose로 검출되었으 며, 그 중 glucose의 함량이 $37 \mathrm{mM}$ 로 가장 높았다. 발효기간 에 따른 누룩의 유리당 함량은 전반적으로 증가하였고, 가 수량에 따른 유리당 함량의 차이는 가수량 $30 \%$ 누룩이 $20 \%$ 누룩보다 glucose, galactose, 및 fructose 함량이 2.4, 1.97 , 및 1.5 배 높았다. 이러한 유리당 함량의 변화는 누룩에 사용되는 전분질 원료, 누룩의 배합 비율 및 발효 미생물의 활성 차이로 전분을 당으로 전환시키는 당화력에 차이에 기인하는 것으로 알려져 있으며(28), 막걸리 등 전통주의 유리당은 알코올 발효의 기질로 이용되어 주류의 향기 생성 과 감미 등에 영향을 주는 것으로 보고되어 있다(29).

가수량을 달리하여 제조한 누룩의 발효기간에 따른 유기 산 함량 결과를 Fig. 6에 나타내었다. 가수량별 제조한 누룩

A

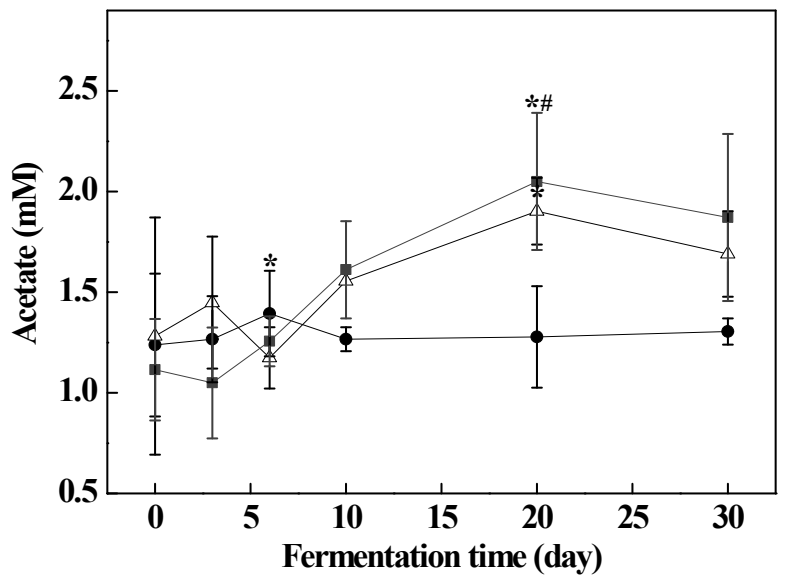

C

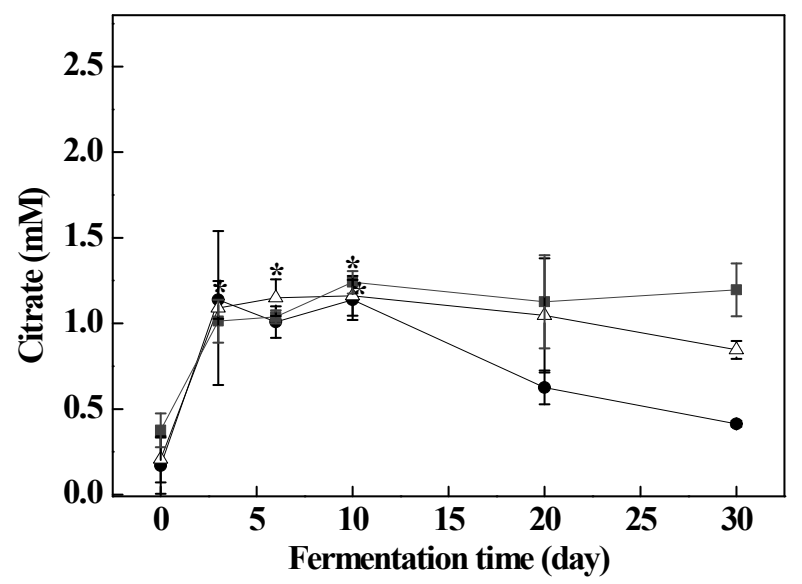

의 주요 유기산은 acetic, citric, butyric 및 lactic acid로 구성 되어 있으며 이 중 가수량 $30 \%$ 누룩의 lactic acid 함량이 약 $2.4 \mathrm{mM}$ 로 가장 높았다. 누룩의 유기산 함량 변화는 가수 량 $26 \%$ 및 $30 \%$ 누룩에서는 발효기간이 경과하면서 acetate, butyrate, citrate 및 lactate 함량이 증가하였다. Baek 등(22)은 밀, 쌀 및 녹두에 누룩곰팡이인 $A$ oryzae, A luchuensis (이전 이름 $A$ kawachii) 및 2종류 종균을 혼용하여 제조한 누룩에서 acetic, citric, formic, fumaric, lactic, malic, 및 oxalic acid 등의 유기산을 확인하였다. 특히, 자연계의 수많 은 미생물을 이용한 자연발효 누룩(재래누룩)이 특정 종균 으로 빚은 누룩보다 citric, lactic, malic acid를 더 많이 생성 하게 되었는데, 이는 누룩제조에 사용한 날곡류뿐만 아니 라 누룩에 생육하는 다양한 미생물에 기인한다고 보고한 바 있다.

본 연구 결과, 가수량 $26 \%$ 및 $30 \%$ 누룩에서는 재래누룩 에서 많이 생성되는 citrate 및 lactate 함량이 발효기간에

B

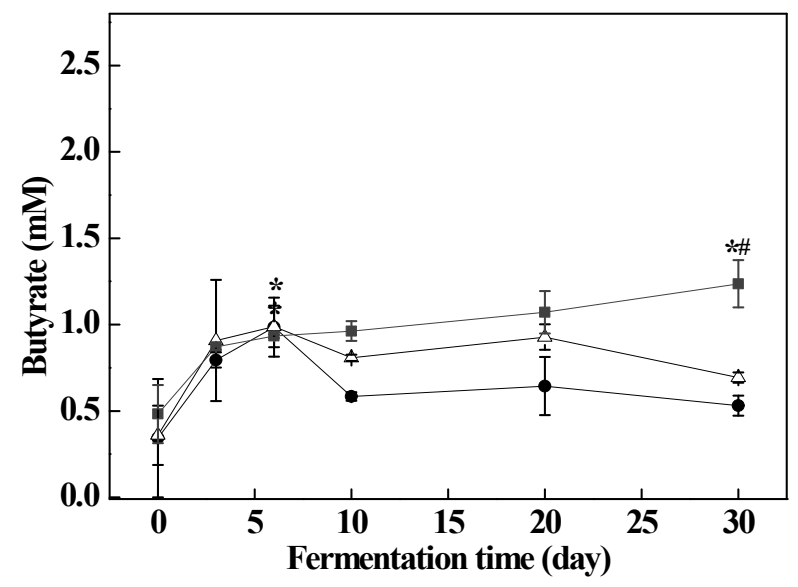

D

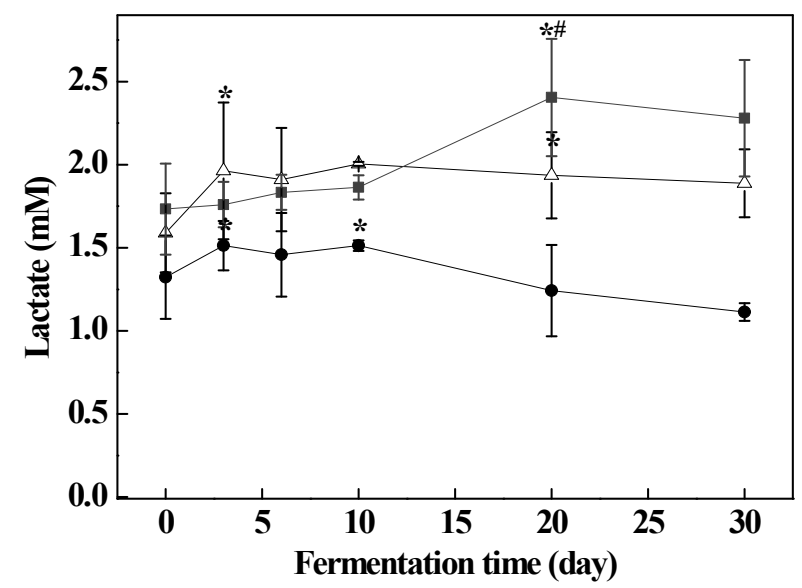

Fig. 6. Organic acid contents of Nuruk with different water contents during fermentation period.

A, acetate; B, butyrate; C, citrate; D, lactate.

$20 \%$ water contents Nuruk $\triangle, 26 \%$ water contents Nuruk $\square, 30 \%$ water contents Nuruk

"Values with different letters within a row differ significantly $(\mathrm{p}<0.05)$. "Values with different letters within a column differ significantly $(\mathrm{p}<0.05)$. Each values represents mean \pm SD $(\mathrm{n}=3)$. 

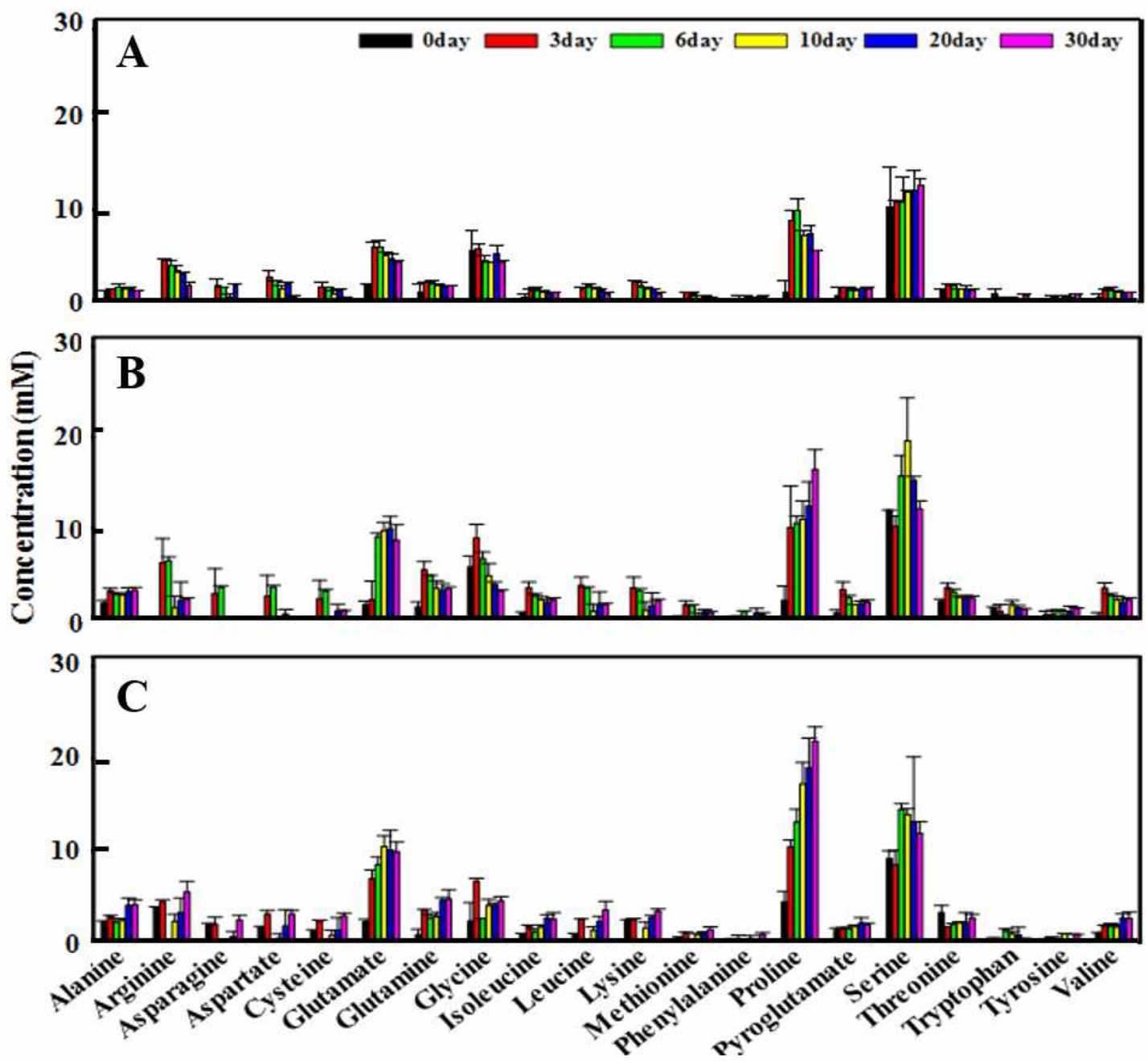

Fig. 7. Free amino acid contents of Nuruk with different water contents during fermentation period. A, 20\% water contents Nuruk, B, 26\% water contents Nuruk, C, 30\% water contents Nuruk

따라 증가하였으나 가수량이 낮은 $20 \%$ 누룩에서는 이러한 결과가 나타나지 않은 것은 누룩제조 시, $26 \%$ 이상의 물을 첨가하는 것이 유기산 조성을 형성하는데 도움이 된다. 유 기산들은 술에서 신맛을 나타내는 중요한 지표물질이며 미량으로 존재할 경우, 맛과 향을 높이는 역할도 하지만, acetic acid가 다량 존재하면 발효과정에서 알코올 성분의 산화로 인한 초산발효 단계로 접어들어 주질을 저하시키는 요인으로 알려져 있다(3).

\section{누룩의 유리아미노산 변화}

가수량을 달리하여 제조한 누룩의 유리 아미노산 변화를 분석한 결과를 Fig. 7에 나타내었다. 주요 유리 아미노산으 로는 arginine, glutamate, glycine, proline, 및 serine 등으로, 필수 아미노산 9개(leucine 등), 비필수 아미노산 11개 (serine 등)를 포함하여 총 20 종의 아미노산이 검출되었다. 발효기간이 경과함에 따라 제조한 3종류 누룩의 유리 아미 노산 함량은 증가하였고, 가수량에 따른 유리 아미노산 함
량은 $26 \%$ 와 $30 \%$ 누룩에서 glutamate, glutamine, glycine, proline, serine threonine, 및 valine 등의 함량이 $20 \%$ 누룩보 다 높았다. 특히 감칠맛을 나타내는 glutamate와 단맛과 쓴 맛을 동시에 나타내는 proline 함량이 발효 중반(10일)부터 후반부(30일)까지 가수량 $20 \%$ 보다 1.1-2배 이상 증가한 것 이 특징이다. Im 등(30)은 쌀로 제조한 누룩에서 약한 쓴맛 을 내는 arginine, lysine, tyrosine, valine과 감칠맛을 내는 glutamic acid, 쓴맛을 내는 leucine, isoleucine, 단맛을 내는 alanine, 쓴맛과 단맛을 내는 proline을 주요 유리 아미노산 으로 검출한 바 있으며, 이들 유리 아미노산의 차이는 사용 하는 곡류의 원료와 더불어 종균의 차이에서 기인한다고 보고하였다.

\section{누룩의 향기성분 변화}

가수량에 따른 누룩의 향기성분 변화를 전자코를 이용하 여 조사한 결과를 Fig. 8 에 나타내었다. 가수량 $26 \%$ 및 $30 \%$ 누룩은 발효 0 일에서 3 일 사이에 향기패턴이 빠르게 변화 
하였으며, 가수량 $20 \%$ 경우, 발효기간이 경과함에 따라 향기패턴이 왼쪽 상단에서 중앙으로 이동하였고, 가수량 $26 \%$ 와 $30 \%$ 누룩의 경우는 발효기간이 경과함에 따라 향기 패턴이 오른쪽 상단에서 하단으로 이동함으로서 향기패턴 이 다르게 나타났다. 이 결과를 바탕으로 가수량에 따른 누룩의 향기성분에 관한 정량적 분석 실험이 추가적으로 수행되어야 한다. Lee 등(21)이 보고한 중온(주·후발효 3 $6^{\circ} \mathrm{C}$ ) 및 고온발효 (주발효 $45^{\circ} \mathrm{C}$, 후발효 $35^{\circ} \mathrm{C}$ ) 밀누룩의 발효 기간별 향기성분 패턴과는 상이한 결과를 얻었다. 이러한 결과는 누룩 제조 시 사용한 단일 원료(밀)과 복합 원료(밀, 보리, 녹두) 및 가수량에 따른 향기성분의 다양한 패턴 변화 를 나타낸다. 전자코 시스템은 전형적인 GC/MS시료 분석 방법과 비교하여 시스템 크기가 작고 특별한 전처리 과정이 필요 없으며 분석시간이 짧아 저가의 혼합 시료에 대한 단순한 상태 변화를 확인할 수 있는 장점을 가진다(31). 본 연구에서는 가수량에 따른 발효기간별 누룩의 향기패턴 변화를 SAW 센서를 이용한 전자코로 신속하게 확인함으 로써 누룩과 같은 다양한 혼합 시료들에 대한 향기패턴 분석에 전자코의 활용이 유용하게 이용될 수 있을 것으로 여겨진다.

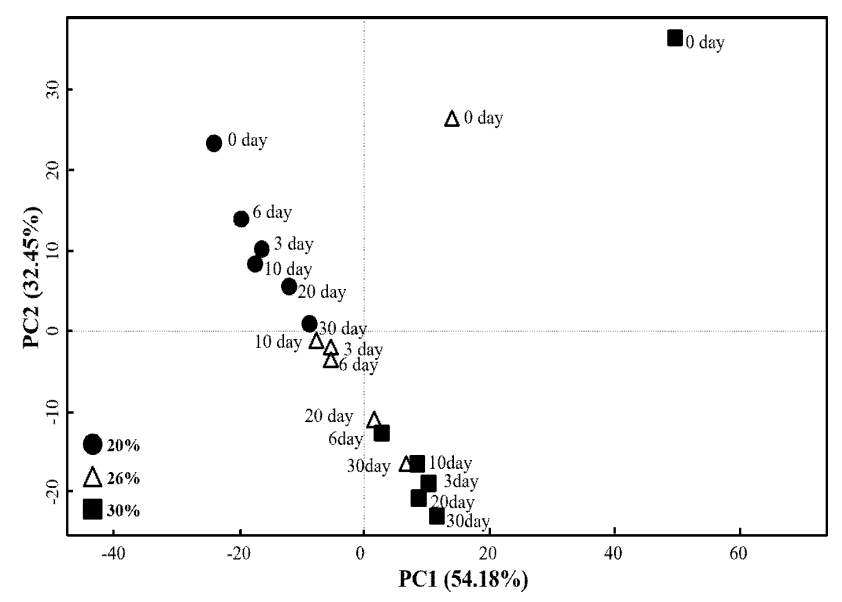

Fig. 8. Principal component analysis (PCA) plot of Nuruk with different water contents during fermentation period.

It was analyzed using the electronic nose.

, $20 \%$ water contents Nuruk, $\triangle, 26 \%$ water contents Nuruk, Nuruk

\section{요 약}

고문헌에 기술된 향온곡의 제조공정을 변형시켜 가수량 을 달리하여 제조한 누룩의 발효기간에 따른 품질 특성을 분석하였다. 본 연구에서 제조한 가수량 $20 \%, 26 \%$ 및 $30 \%$ 누룩은 가수량에 상관없이 발효기간이 경과함에 따라 곰팡 이 균사가 내부까지 침투하여 생육하였고, 중량 및 크기 또한 가수량에 따른 차이는 없었으나, 발효기간 동안 전체
적으로 소폭 감소하였다. 누룩의 품온 변화는 가수량 $26 \%$ 누룩에서 가장 높은 $39.7^{\circ} \mathrm{C}$ 의 품온을 나타내었고, $\mathrm{pH}$ 는 가 수량이 높은 누룩일수록 더 낮게 나타났다. a-Amylase 활성 은 가수량 $30 \%$ 누룩이 $20 \%$ 누룩보다 약 1.5 배 더 높았고, glucoamylase 활성은 가수량 $20 \%$ 누룩이 발효 20 일째 4,424.6 units/g으로, $26 \%$ 및 $30 \%$ 누룩과 비교하여 유의적으 로 높았다. Acidic protease 활성은 가수량 $30 \%$ 누룩이 발효 20 일에 $1,800 \mathrm{units} / \mathrm{g}$ 로 가수량 $20 \%, 26 \%$ 누룩보다 높았다. 유리당은 가수량 $30 \%$ 누룩이 $20 \%$ 누룩보다 glucose, galactose 및 fructose 함량이 2.4, 1.97 및 1.5배 높았고, 유기 산은 가수량 $30 \%$ 누룩의 lactic acid가 약 $2.2 \mathrm{mM}$ 로 가장 높았다. 유리 아미노산은 $26 \%$ 및 $30 \%$ 누룩에서 glutamate, glutamine, glycine, proline, serine threonine, 및 valine 등의 함량이 가수량 $20 \%$ 누룩보다 높았다. 가수량 $20 \%$ 누룩은 발효기간이 경과함에 따라 향기패턴이 왼쪽 상단에서 중앙 으로 이동하였고, $26 \%$ 와 $30 \%$ 누룩은 오른쪽 상단에서 하 단으로 이동하였다. 본 연구 결과를 종합적으로 분석해보 면, 가수량 $26 \%$ 이상으로 제조한 누룩의 품질이 우수한 것으로 생각되고, 향후 전통누룩의 상업화 과정에 기초자 료로 활용될 것으로 사료된다.

\section{감사의 글}

이 논문은 농촌진흥청 농업과학기술개발사업(과제번호: PJ01242501)의 지원에 의해 이루어진 것이며, 연구비 지원 에 감사드립니다.

\section{References}

1. Park JH, Chung CH (2014) Characteristics of Takju (a cloudy Korean rice wine) prepared with Nuruk (a traditional Korean rice wine fermentation starter), and identification of lactic acid bacteria in Nuruk Korean J Food Sci Technol, 46, 153-164

2. Jo KY, Ha DM (1995) Isolation and identification of the lactic acid bacteria from Nuruk J Korean Soc Appl Biol Chem, 38, 95-99

3. Woo SM, Shin JS, Seong JH, Yeo SH, Choi HJ, Kim TY, Jeong YJ (2010) Quality characteristics of brown rice Takju by different Nuruks. J Korean Soc Food Sci Nutr, 39, 301-307

4. So MH (1999) Characteristics of a modified nuruk made by inoculation of traditional nuruk microorganisms. Korean J Food Sci Technol, 12, 219-225

5. Yu TS, Kim J, Kim HS, Hyun JS, Ha HP, Park MG 
(1998) Bibliographical study on microorganism of traditional Korean Nuruk (since 1945). J Korean Soc Food Sci Nutr, 27, 789-799

6. Kim HS, Hyun JS, Kim J, Ha HP, Yu TS (1997) Characteristics of useful fungi isolation from traditional Korean Nuruk J Korean Soc Food Sci Nutr, 26, 767-774

7. Jo GY, Lee CW (1997) Isolation and identification of the fungi from Nuruk J Korean Soc Food Sci Nutr, 26, 759-766

8. Lee JH, Yu TS (2000) Identification and characteristics of lactic acid bacteria isolated from Nuruk Korean J Biotechnol Bioeng, 15, 359-365

9. Lee SH Jung HJ, Yeo SH, Kim HS, Yu TS (2004) Characteristics of a-amylase of a new species, Aspergillus coreanus NR 15-1. Korean J Biotechnol Bioeng, 19, 301-307

10. Lee JK, Jo HJ, Yoon JA, Chung KH, Song BC, Kim $\mathrm{KI}$, An JH (2014) Isolation and identification of microorganisms with antimicrobial activity in Makgeolli of different kinds koji and Nuruk J Korean Soc Food Sci Nutr, 43, 577-583

11. Lee MK, Lee SW, Bae SM (1991) The quality of Yakju brewed from many kind of Nuruk J East Asian Soc Diet Life, 1, 99-111

12. Park CS, Lee TS (2002) Quality characteristics of Takju prepared by wheat flour Nuruk Korean J Food Sci Technol, 34, 296-302

13. Jung HK, Park CD, Park HH, Lee GD, Lee IS, Hong JH (2006) Manufacturing and characteristics of Korean traditional liquor, Hahyanju prepared by Saccharomyces cerevisiae HA3 isolated from traditional Nuruk Korean J Food Sci Technol, 38, 659-667

14. Kim MS, Lee YH, Kim IY, Eom TK, Kim SH (2013) Physicochemical characteristics of Korean traditional spirits brewed with Phellinus linteus by different Nuruk J Korean Soc Food Sci nutr, 42, 2042-2048

15. Lee TS, Choi JY (2005) Volatile flavor components in mash of Takju prepared by using Aspergillus kawachii Nuruks. Korean J Food Sci Technol, 37, 944-950

16. Yoon CG, Chae SN, Huh NE, Kim HS, Yu TS (1999) Effects of Nuruk or wheat bran supplemented diet on the serum levels of cholesterol and activities of hepatic oxygen free radical metabolizing enzymes in rats. $\mathbf{J}$ Korean Soc Food Sci Nutr, 28, 212-217

17. Lee DY, Lee SJ, Kwak HY, Jung L, Heo J, Hong S, Kim GW, Baek NI (2009) Sterols isolated from Nuruk (Rhizopus oryzae KSD-815) inhibit the migration of cancer cells. J Microbiol Biotechnol, 19, 1328-1332

18. Jung HK, Park CD, Lee GD, Park SC, Park HH, Hong JH (2007) Characteristics of Pichia anomala K15 producing killer toxin isolated from traditional Nuruk J Korean Soc Food Sci Nutr, 36, 1077-1082

19. Eun KJ, Jung SK, Lee SJ, Lee KW, Kim GW, Lee HJ (2008) Nuruk extract inhibits lipopolysaccharide- induced production of nitrite and interleukin-6 in RAW 264.7 cells through blocking activation of p38 mitogenactivated protein kinase. J Microbiol Biotechnol, 18, 1423-1426

20. U SK (1554) Hyangonguk. Kosachalyo, Korea

21. Lee SH, Baek SY, Kang JE, Jeon CO, Kim DH, Kim $\mathrm{MD}$, Yeo SH (2015) Effects of temperature on the changes of enzymatic activities and metabolite during wheat Nuruk fermentation. Microbiol Biotechnol Lett, 43, 378-384

22. Baek SY, Kim JY, Choi JH, Choi JS, Choi HS, Jeong ST, Yeo SH (2012) Assessment of the quality characteristics of mixed-grain Nuruk made with different fungal strains. J East Asian Soc Diet Life, 22, 103-108

23. Noh JH, Choi JH, Jung ST, Yeo SH, Park JW, Lee JW, Choi HS (2013) Mycelial production and amylase activity of fungi for brewing in different submerged culture conditions. J East Asian Soc Diet Life, 23, 833-838

24. Choi JH, Jeon JA, Jung ST, Park JH, Park SY, Lee CH, Kim TJ, Choi HS, Yeo SH (2011) Quality characteristics of Seoktanju fermented by using different commercial Nuruks. Korean J Microbiol Biotechnol, 39, 56-62

25. Wolfgang K (1994) Technologie brauer und malzer. VLB Berlin, Berlin, Germany, p 306

26. Park JH, Yeo SH, Jeong ST, Choi HS, Jeon JA, Choi JH (2010) Characteristics of Byeok-hyang-ju made by various procesing methods originated from ancient documents. Korean J Food Preserv, 17, 826-834

27. Kim MS, Jeon JA, Jeong ST, Choi JH, Choi HS, Yeo SH (2011) Characteristics of Byeo-Nuruk according to the mixing ration of wheat and the addition rate of moisture. J East Asian Soc Diet Life, 21, 897-904

28. Jeon JW, Park KJ, Kim MH, Kim DS (2006) Quality characteristics of Takju fermentation by addition of chestnut peel power. Korean J Food Preserv, 13, 329-336

29. Lee JS, Lee TS, Noh BS, Park SO (1996) Quality characteristics of mash of Takju prepared by different raw materials. Korean J Food Sci Technol, 28, 330-336

30. Im SY, Baek CH, Baek SY, Park HY, Choi HS, Choi JH, Jeong ST, Shin WC, Park HD, Yeo SH (2014) Quality 
characteristics of Takju according to different rice varieties and mixing ratio of Nuruk Korean J Food Preserv, 21, 892-902
31. Kim KW, Kim AH, Lee JK, Chun MS, Noh BS (2014) Analysis of flavor pattern of various coffee beans using electronic nose. Korean J Food Sci Thechnol, 46, 1-6 